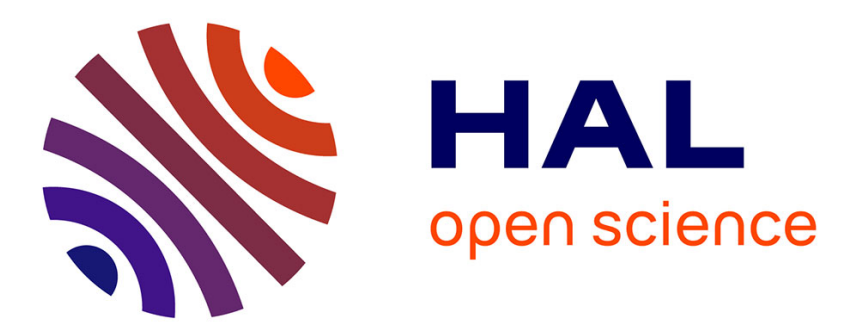

\title{
Trace element concentrations in European pond turtles (Emys orbicularis) from Brenne Natural Park, France
} Héloïse Guillot, Xavier Bonnet, Paco Bustamante, Carine Churlaud, Jacques Trotignon, Francois Brischoux

\section{- To cite this version:}

Héloïse Guillot, Xavier Bonnet, Paco Bustamante, Carine Churlaud, Jacques Trotignon, et al.. Trace element concentrations in European pond turtles (Emys orbicularis) from Brenne Natural Park, France. Bulletin of Environmental Contamination and Toxicology, 2018, 101 (3), pp.300-304. 10.1007/s00128-018-2376-7 . hal-02012000

\author{
HAL Id: hal-02012000 \\ https://hal.science/hal-02012000
}

Submitted on 28 Feb 2019

HAL is a multi-disciplinary open access archive for the deposit and dissemination of scientific research documents, whether they are published or not. The documents may come from teaching and research institutions in France or abroad, or from public or private research centers.
L'archive ouverte pluridisciplinaire HAL, est destinée au dépôt et à la diffusion de documents scientifiques de niveau recherche, publiés ou non, émanant des établissements d'enseignement et de recherche français ou étrangers, des laboratoires publics ou privés. 


\section{Trace element concentrations in European pond turtles (Emys orbicularis) from Brenne Natural Park, France}

Héloïse Guillot ${ }^{1}$, Xavier Bonnet ${ }^{1}$, Paco Bustamante ${ }^{2}$, Carine Churlaud ${ }^{2}$, Jacques Trotignon 3 , François Brischoux ${ }^{1}$

1. Centre d'Etudes Biologiques de Chizé, CEBC UMR 7372 CNRS-ULR, 79360 Villiers en Bois, France

2. Littoral Environnement et Sociétés (LIENSs), UMR 7266 CNRS-Université de La Rochelle, 2 rue Olympe de Gouges, 17000 La Rochelle, France

3. Réserve Naturelle Nationale de Chérine, Maison de la Nature et de la Réserve, 36290 Saint-Michel-en-Brenne, France

Correspondence:

François Brischoux, francois.brischoux@gmail.com

Centre d'Etudes Biologiques de Chizé, CEBC-CNRS UPR 1934, 79360 Villiers en Bois, France 
Abstract: We assessed trace elements concentration in European pond turtle (Emys orbicularis) from Brenne Natural Park (France). We sampled road-killed turtles ( $\mathrm{N}=$ 46) to measure the concentrations of 4 non-essential $(\mathrm{Ag}, \mathrm{Cd}, \mathrm{Hg}$, and $\mathrm{Pb})$ and 10 essential (As, Co, Cr, Cu, Fe, Mn, Ni, Se, V, and Zn) elements in muscle, skin, liver and claws. Body size or sex did not influence the concentrations of most elements; except for $\mathrm{Hg}$ (liver, skin and claws) and $\mathrm{Zn}$ (muscle) which increased with body size. We found relatively high concentrations of $\mathrm{Hg}$ and $\mathrm{Zn}$, possibly linked to fish farming. This result deserves future investigations to evaluate possible ecotoxicological effects on E. orbicularis.

Keywords: trace elements; contamination; wetlands; Emys orbicularis 


\section{Introduction}

Wetlands are important habitats for biodiversity, yet they are among the most endangered ecosystems in the world, suffering from a drastic reduction of their surface and from a degradation of water quality (Schneider et al. 2017). Monitoring environmental contaminations in wetlands is difficult because they are connected to complex and large hydric networks composed by both surface and underground waters. As a consequence, the connectivity of aquatic systems can induce contamination in areas that otherwise appear unscathed from direct sources of pollution (Baker 1992). Among environmental contaminants, trace elements are wellknown for their ability to enter and move across aquatic environments (Agarwal 2009). These elements comprise both non-essential elements (that exhibit high toxicity at low concentrations) and essential elements (that may become toxic when they exceed normal levels) (Förstner and Wittman 1981). Overall, trace elements represent a threat to aquatic ecosystems because of their high toxicity, persistence, bioaccumulation in organisms and Biomagnification across trophic levels (Agarwal 2009).

Freshwater turtles are suitable organisms to survey contamination levels in complex aquatic ecosystems (Overmann and Krajicek 1995; Ayub et al. 2001; Nagle et al. 2001; Bergeron et al. 2007; Yu et al. 2011; Malik et al. 2013; Yadollahvand et al. 2014; Allender et al. 2015; Slimani et al. 2018). First, they are widely distributed and occupy a variety of habitats. Second, they have a long life expectancy, which allows studying bioaccumulation processes and long-term trends of contaminants. Finally, most species are sedentary and provide information on the contamination at a precise location. 
In this study, we used opportunistic sampling of roadkilled European pond turtles (Emys orbicularis) to study trace element contamination of one of the largest French wetlands: the Brenne Natural Park. The goals of our descriptive study were to document the concentrations of 4 nonessential trace elements ( $\mathrm{Ag}, \mathrm{Cd}, \mathrm{Hg}$, and $\mathrm{Pb}$ ) and 10 essential trace elements (As, $\mathrm{Co}, \mathrm{Cr}, \mathrm{Cu}, \mathrm{Fe}, \mathrm{Mn}, \mathrm{Ni}, \mathrm{Se}, \mathrm{V}$, and $\mathrm{Zn}$ ) in the muscle, skin, liver and claws of E. orbicularis; and to investigate the relationship between the concentrations of these elements and the sex and the size of the turtles.

\section{Material and methods}

Emys orbicularis is a small European freshwater turtle species (Priol et al. 2008). Carcasses of accidentally killed pond turtles were found on roads situated in vicinity of the Réserve Naturelle Nationale de Chérine $\left(46^{\circ} 47^{\prime} 25.23^{\prime \prime} \mathrm{N}, 1^{\circ} 12^{\prime} 3.54^{\prime \prime} \mathrm{E}\right)$ between 2008 and 2014. A total of 46 turtles were collected including 38 adults (17 females, 16 males, 5 unsexed individuals) and 8 juveniles. We used plastron length as an index of body size.

All individuals were dissected to take samples of the posterior right leg muscles and skin, liver and claws (Table 1). Because of the limiting mass of the claw samples, only $\mathrm{Hg}$ concentrations were measured in this tissue. The muscles, skin and liver samples were lyophilized and hand-ground with a porcelain mortar and pestle. Claws were washed three times with a mixture of 2:1 chloroform/methanol solution in an ultrasonic cleaner and rinsed in milli-Q quality water. Claws were then dried for $48 \mathrm{~h}$ at $50^{\circ} \mathrm{C}$. The average weights of the tissue samples used for trace element analysis were $200 \mathrm{mg}$ for muscles samples, $215 \mathrm{mg}$ for skin samples, $119 \mathrm{mg}$ for liver samples and $12 \mathrm{mg}$ for claws. 
Total Hg concentrations were measured using and atomic absorption spectrophotometer (Advanced Mercury Analyser-254, Altec) on dried tissue aliquots (ranging from 2 to $10 \mathrm{mg}$ ) as described by Chouvelon et al. (2009). Accuracy was checked using TORT-2 Lobster Hepatopancreas (NRC, Canada; certified Hg concentration: $0.27 \pm 0.06 \mu \mathrm{g} \mathrm{g}^{-1} \mathrm{dw}$ ) as certified reference material (CRM). Our measured values were $0.245 \pm 0.003 \mu \mathrm{g} \mathrm{g}^{-1} \mathrm{dw}(\mathrm{N}=4)$ showing a recovery of $91 \%$. Blanks were analysed at the beginning of each set of samples and the detection limit of the method was $0.05 \mathrm{ng}$.

Other elements (Table 1) were analysed using a Varian Vista-Pro ICP-OES and a Thermo Fisher Scientific X Series 2 ICP-MS (following Kojadinovic et al. 2011). CRM (DOLT-4 dogfish liver and TORT-3 Lobster Hepatopancreas, NRC, Canada) and blanks treated and analysed in the same way as the samples were included in each analytical batch. The recovery ratio were in good agreement with DOLT-4 [94\% (Ag); 99\% (As); 105\% (Cd); 104\% (Cu); 90\% (Fe); 99\% (Ni); 87\% (Pb); 101\% (Se) and 101\% (Zn)] and TORT-3 [109\% (As); 101\% (Cd); 101\% (Co); 95\% (Cr); 103\% (Cu); 86\% (Fe); 96\% (Mn); 97\% (Ni); 93\% (Pb); 101\% (Se); 99\% (V) and 96\% (Zn)]. The limits of quantification $(\mu \mathrm{g} g-1)$ were $0.01(\mathrm{Ag}, \mathrm{Co}, \mathrm{Cd}, \mathrm{Mn}, \mathrm{Pb}) ; 0.12(\mathrm{As}, \mathrm{Cr}) ; 0.02(\mathrm{Cu}) ; 5.03$ (Fe, $\mathrm{Zn}) ; 0.05(\mathrm{Ni}) ; 0.5(\mathrm{Se}) ;$ and $1.26(\mathrm{~V})$. Trace element concentrations are expressed in $\mu g \mathrm{~g}^{-1} \mathrm{dw}$.

When trace elements concentrations were lower than the limit of detection (LoD) in more than $30 \%$ of the samples (Table 1), these samples were excluded from statistical analyses (EPA 2000). When trace elements concentrations were lower than LoD in 
less than $30 \%$ of the samples, values below LoD were replaced by $(\mathrm{LoD}) \times 0.5$ for statistical analyses (EPA 2000). To investigate the influence of sex on trace element concentrations, possible sexual size dimorphism was considered: plastron length was compared between sexes with a Kruskal-Wallis test (data were not normally distributed). Because females were larger than males (see results), we used ANCOVAs to test for sex effects in trace element concentrations, using plastron length as the covariate. To investigate the influence of body size (hence presumably age) on trace element concentrations, and thus the bioaccumulation of these elements through time, we used Spearman rank's correlation between trace elements and plastron length.

\section{Results and Discussion}

The mean concentrations of each trace element are presented in Table 1. Only four elements ( $\mathrm{Cd}$ in muscle and skin; $\mathrm{Cr}$ in liver; $\mathrm{Ag}$ in muscle, skin and liver and $\mathrm{V}$ in muscle, skin and liver) were below the LoD in $>30 \%$ of individuals (Table 1 ).

Although females were larger than males (Kruskal-Wallis $\chi^{2}=19.7449$, df $=1, p<$ 0.01), sex did not influence the concentrations of trace elements (all $\mathrm{p}>0.12$ ). This suggests that feeding, metabolism or growth rates were broadly similar for both genders (Allender et al. 2015; Yu et al. 2011) and that contrarily to what has been shown in another species (Nagle et al. 2001) or in sea turtles (Guirlet et al. 2008), eggs may not represent a major excretion pathway in female E. orbicularis.

Most trace elements concentrations did not correlate with body size suggesting that E. orbicularis does not bioaccumulate these contaminants with age as showed in other 
turtle species (Allender et al. 2015; Yadollahvand et al. 2014). Yet, and similarly to other studies (Overmann and Krajicek 1995; Nagle et al. 2001; Bergeron et al. 2007; Yu et al. 2011), we found two notable exceptions to this trend: Zn concentrations (in muscle, $\mathrm{r}_{\mathrm{s}}=0.49, \mathrm{p}<0.05$; Fig. 1) and Hg concentrations (in liver, skin and claws) were correlated with body size (respectively $\mathrm{r}_{\mathrm{s}}=0.56, \mathrm{p}<0.05 ; \mathrm{r}_{\mathrm{s}}=0.44, \mathrm{p}<0.05 ; \mathrm{r}_{\mathrm{s}}=$ $0.40, \mathrm{p}<0.05$; Fig. 2). These results suggest that these elements bioaccumulate over the life of the turtle. Interestingly, these two elements were found in relatively high concentrations (up to $208 \mu \mathrm{g} \mathrm{g}^{-1} \mathrm{dw}$ for $\mathrm{Zn}$ and $4.451 \mu \mathrm{g} \mathrm{g} \mathrm{g}^{-1} \mathrm{dw}$ for $\mathrm{Hg}$ ), suggesting that excretion rates do not compensate for $\mathrm{Zn}$ and $\mathrm{Hg}$ exposure.

Bioaccumulation of $\mathrm{Hg}$ in its methylated form is a well-known process in vertebrates as this non-essential metal is not regulated and bound to proteins potentially leading to adverse effects (Eagles-Smith et al. 2018). It is noteworthy that the value of $\mathrm{Hg}$ we report in various tissues of E. orbicularis are among the highest reported for freshwater turtles (Yu et al. 2011; Zapata et al. 2014; Slimani et al. 2018), and the consequences of such high values should be investigated.

$\mathrm{Zn}$ is an essential metal subjected to homeostatic regulation as it included in the functional groups of various enzymes, play a structural role in respiratory pigments and metalloenzymes, and can act as activating co-factor for various proteins (see e.g. Simkiss 1979; Williams 1981). Accordingly, Zn concentrations measured here could be physiological and thus not a problem on the health status of E. orbicularis. Nonetheless, the increase of $\mathrm{Zn}$ concentrations with age is likely due to its accumulation on specific metalloproteins such as metallothioneins, which serve as intracellular protein in metal homeostasis (Vallee 1991). Future investigations on 
metallothioneins in E. orbicularis would be needed to validate this hypothesis. In addition, the values we report are substantially higher than those reported for other species of turtles (Malik et al. 2013; Yadollahvand et al. 2014), and the potential effects of such high values of Zn should be investigated.

Although the sources of $\mathrm{Hg}$ and $\mathrm{Zn}$ contamination remain unknown, several hypotheses can be proposed. For instance, the concentrations of $\mathrm{Hg}$ we detected may be related to a natural contamination due to the methylating activity of microorganisms in anoxic sediments rather than a direct anthropogenic source of contamination (Morel et al. 1998). Alternatively, relatively high concentrations of both $\mathrm{Hg}$ and $\mathrm{Zn}$ could be linked to the composition of fish pellets used for fish farming that occur in many ponds of Brenne. Indeed, commercial fish pellets exhibit high $\mathrm{Hg}$ concentrations of marine origin (Hansson et al. 2017; see also Lemaire et al. 2018) and are enriched with Zn oxide (EFSA 2012). Future studies should usefully investigate both the origin of $\mathrm{Hg}$ and $\mathrm{Zn}$ as well as the physiological and toxicological consequences of elevated levels of these elements for E. orbicularis (Meyer et al. 2014).

\section{Acknowledgments}

We warmly thank the staff from the Réserve Naturelle Nationale de Chérine and M. Brault-Favrou for assistance in trace element analyses. The CPER (Contrat de Projet Etat-Région) for funding the ICPs and AMA. Funding was provided by the Région Poitou-Charentes, the Conseil Départemental des Deux-Sèvres, the CNRS, the Agence de l'Eau Loire-Bretagne and the Agence de l'eau Adour-Garonne. The IUF 
(Institut Universitaire de France) is also acknowledged for its support to PB as a Senior Member.

\section{References}

Agarwal S. K., 2009. Heavy Metal Pollution. APH Publishing Corporation.

Allender M.C., Dreslik M.J., Patel B., Luber E.L., Byrd J., Phillips C.A. and Scott J.W., 2015. Select metal and metalloid surveillance of free-ranging Eastern box turtles from Illinois and Tennessee (Terrapene Carolina carolina). Ecotoxicology $24,1269-1278$.

Ayub M., Khan W.A. and Tabinda A.B., 2001. Determination of some heavy/trace metals in two species of turtles (Lissemys punctata and Trionyx Gangeticus) collected from different spots of Hadiara drain. Pakistan Journal of Fisheries 2, 43-48.

Baker L.A., 1992. Introduction to nonpoint source pollution in the United States and prospects for wetland use. Ecological Engineering 1, 1-26.

Bergeron CM, Husak JF, Unrine JM, Romanek CS, Hopkins WA (2007) Influence of feeding ecology on blood mercury concentrations in four species of turtles. Environ Toxicol Chem 26:1733-1741

Chouvelon T, Warnau M, Churlaud C, Bustamante P (2009) Hg concentration and related risk assessment in coral reef crustaceans, molluscs and fish from New Caledonia. Environ Pollut 157:331-340

Eagles-Smith CA, Silbergeld EK, Basu N, Bustamante P, Diaz-Barriga F, Hopkins WA, Kidd KA, Nyland JF (2018) Modulators to mercury risk to wildlife and humans in the context of rapid global change. Ambio 47(2):170-197

EFSA Panel on Additives and Products or Substances used in Animal Feed (FEEDAP), 2012. Scientific Opinion on safety and efficacy of zinc compounds (E6) as feed additive for all animal species: Zinc oxide, based on a dossier submitted by Grillo Zinkoxid GmbH/EMFEMA. EFSA Journal 10,2970-2994. 
EPA (U.S. Environmental Protection Agency), 2000. Guidance for Data Quality Assessment: Practical Methods for Data Analysis (EPA/600/R-96/084) (Washington, DC).

Förstner U., Wittman G.T.W., 1981. Metal pollution in the aquatic environment. Berlin, Heidelberg. Germany: Springer-Verlag, 272,486.

Guirlet E, Das K, Girondot M (2008) Maternal transfer of trace elements in leatherback turtles (Dermochelys coriacea) of French Guiana. Aquat Toxicol $88: 267-276$

Hansson SV, Sonke J, Galop D, Bareille G, Jean S, Roux G (2017) Transfer of marine mercury to mountain lakes. Sci Rep 7:12719

Kojadinovic J, Jackson CH, Cherel Y, Jackson GD, Bustamante P (2011) Multielemental concentrations in the tissues of the oceanic squid Todarodes filippovae from Tasmania and the Southern Indian Ocean. Ecotoxicol Environ Saf 74:1238-1249

Lemaire J, Bustamante P, Olivier A, Lourdais O, Michaud B, Boissinot A, Galan P, Brischoux F (2018) Determinants of mercury contamination in viperine snakes, Natrix maura, in Western Europe. Sci Total Environ 635:20-25

Malik RN, Ghaffar B, Hashmi MZ (2013) Trace metals in Ganges softshell turtle (Aspideretes gangeticus) from two barrage: Baloki and Rasul, Pakistan. Environ Sci Pollut Res 20:8263-8273

Meyer E, Eagles-Smith CA, Sparling D, Blumenshine S (2014) Mercury Exposure associated with altered plasma thyroid hormones in the declining Western Pond Turtle (Emys marmorata) from California Mountain Streams. Environ Sci Technol 48:2989-2996

Morel FMM, Kraepiel ANL, Amyot M (1998) The chemical cycle and bioaccumulation of mercury. Annu Rev Ecol Syst 29:543-566

Nagle RD, Rowe CL, Congdon JD (2001) Accumulation and selective maternal transfer of contaminants in the turtle Trachemys scripta associated with coal ash deposition. Arch Environ Contam Toxicol 40:531-536 
Overmann SR, Krajicek JJ (1995) Snapping turtles (Chelydra serpentine) as biomonitors of lead contamination of the Big River in Missouri's old lead belt. Environ Toxicol Chem 14:689-695

Priol P, Coic C, Servan J (2008) Répartition de la cistude d'Europe (i) en aquitaine. Bull SHF 127:23-34

Schneider C, Flörke M, De Stefano L, Petersen-Perlman JD (2017) Hydrological threats to riparian wetlands of international importance - a global quantitative and qualitative analysis. Hydrol Earth Syst Sci 21:2799-2815

Simkiss K (1979) Metal ions in cells. Endeavour 3:2-6

Slimani T, El Hassani MS, El Mouden EH, Bonnet M, Bustamante P, Brischoux F, Brault-Favrou M, Bonnet X (2018) Large-scale geographic patterns of mercury contamination in Morocco revealed by freshwater turtles. Environ Sci Pollut Res 25:2350-2360

Vallee BL (1991) Introduction to metallothionein. In: Riordan JF, Vallee BL (eds) Metallobiochemistry, metallothionein and related molecules, Methods in enzymology. vol 205. Academic Press, San Diego, pp 3-7

Williams RJP (1981) The Bakerian lecture, 1981: natural selection of the chemical elements. Proc R Soc Lond B Biol Sci 213:361-397

Yadollahvand R, Kami HG, Mashroofeh A, Riyahi Bakhtiari A (2014) Assessment trace elements concentrations in tissues in Caspian Pond Turtle (Mauremys caspica) from Golestan province, Iran. Ecotoxicol Environ Saf 101:191-195

Yu S, Halbrook RS, Sparling DW, Colombo R (2011) Metal accumulation and evaluation of effects in a freshwater turtle. Ecotoxicology 20:1801-1812

Zapata L, Bock B, Palacio J (2014) Mercury concentrations in tissues of Colombian slider turtles, Trachemys callirostris, from northern Colombia. Bull Environ Contam Toxicol 92(5):562-566 
Table 1. Trace elements concentrations $\left(\mu \mathrm{g} \mathrm{g}^{-1} \mathrm{dw}\right)$ in skin, muscle, liver and claws (Hg only) of E. orbicularis.

\begin{tabular}{|c|c|c|c|c|c|c|c|c|}
\hline \multirow[t]{2}{*}{ Elements } & \multicolumn{2}{|c|}{ Muscle } & \multicolumn{2}{|l|}{ Skin } & \multicolumn{2}{|l|}{ Liver } & \multicolumn{2}{|l|}{ Claws } \\
\hline & $\mathrm{N}$ & Mean \pm SD & $\mathrm{N}$ & Mean \pm SD & $\mathrm{N}$ & Mean \pm SD & $\mathrm{N}$ & Mean \pm SD \\
\hline \multicolumn{9}{|l|}{ Essential } \\
\hline As & $35 / 39$ & $0.64 \pm 0.39$ & $42 / 44$ & $1.17 \pm 1.02$ & $15 / 16$ & $0.56 \pm 0.57$ & - & - \\
\hline Co & $39 / 39$ & $0.14 \pm 0.09$ & $44 / 44$ & $0.18 \pm 0.19$ & $16 / 16$ & $0.48 \pm 0.91$ & - & - \\
\hline $\mathrm{Cr}$ & $39 / 39$ & $7.36 \pm 4.55$ & $42 / 43$ & $4.00 \pm 2.04$ & $8 / 16$ & $3.87 \pm 12.68$ & - & - \\
\hline $\mathrm{Cu}$ & $39 / 39$ & $5.00 \pm 0.82$ & $44 / 44$ & $3.02 \pm 0.92$ & $16 / 16$ & $11.98 \pm 4.54$ & - & - \\
\hline $\mathrm{Fe}$ & $39 / 39$ & $279 \pm 115$ & $42 / 42$ & $316 \pm 173$ & $11 / 11$ & $464 \pm 164$ & - & - \\
\hline Mn & $34 / 34$ & $6.79 \pm 4.72$ & $40 / 40$ & $14.32 \pm 13.68$ & $16 / 16$ & $10.44 \pm 13.41$ & - & - \\
\hline $\mathrm{Ni}$ & $39 / 39$ & $2.72 \pm 2.13$ & $43 / 43$ & $1.61 \pm 0.82$ & $15 / 16$ & $0.63 \pm 1.42$ & - & - \\
\hline $\mathrm{Se}$ & $38 / 38$ & $3.17 \pm 1.03$ & $44 / 44$ & $2.25 \pm 0.83$ & $16 / 16$ & $7.56 \pm 7.89$ & - & - \\
\hline $\mathrm{V}$ & $0 / 39$ & $<\mathrm{LoD}$ & $2 / 44$ & $0.99 \pm 0.12$ & $5 / 17$ & $9.64 \pm 4.51$ & - & - \\
\hline $\mathrm{Zn}$ & $39 / 39$ & $161 \pm 30$ & $44 / 44$ & $64 \pm 15$ & $16 / 16$ & $139 \pm 36$ & - & - \\
\hline \multicolumn{9}{|c|}{ Non-essential } \\
\hline $\mathrm{Ag}$ & $15 / 39$ & $0.019 \pm 0.010$ & $25 / 44$ & $0.026 \pm 0.021$ & $11 / 17$ & $0.027 \pm 0.016$ & - & - \\
\hline $\mathrm{Cd}$ & $26 / 39$ & $0.015 \pm 0.012$ & $24 / 44$ & $0.013 \pm 0.012$ & $15 / 15$ & $0.129 \pm 0.123$ & - & - \\
\hline $\mathrm{Hg}$ & $39 / 39$ & $0.662 \pm 0.375$ & $44 / 44$ & $0.484 \pm 0.367$ & $17 / 17$ & $1.128 \pm 1.077$ & $43 / 43$ & $1.346 \pm 0.939$ \\
\hline $\mathrm{Pb}$ & $39 / 39$ & $0.21 \pm 0.19$ & $44 / 44$ & $0.36 \pm 0.31$ & $16 / 18$ & $0.74 \pm 2.51$ & - & - \\
\hline
\end{tabular}

$\mathrm{N}=$ sample with concentration above the limit of detection $(\mathrm{LoD}) /$ total sample size 


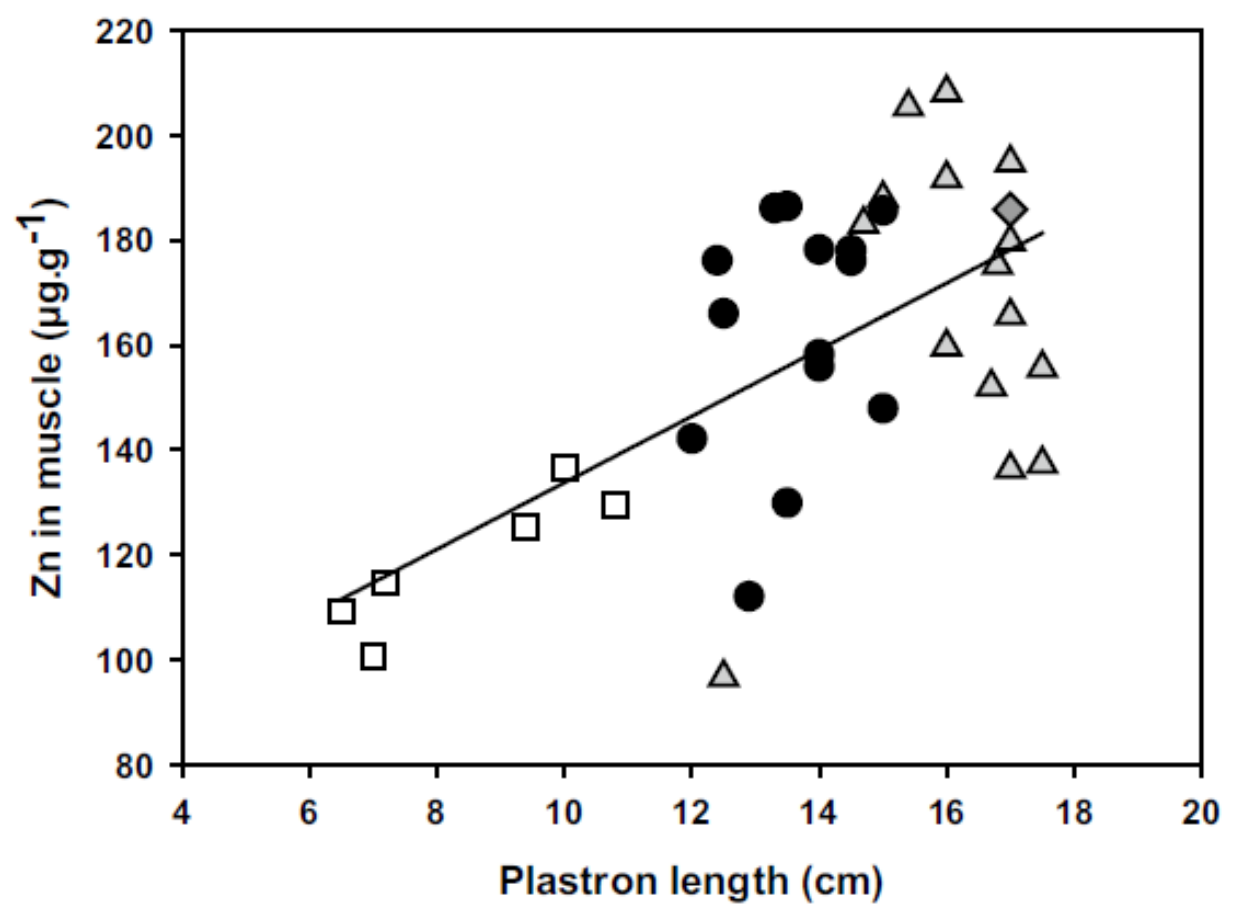

Figure 1. Relationship between turtle size (plastron length) and concentrations of $\mathrm{Zn}$ in muscles. Symbols stand as follow: white squares for juveniles, black circles for adult males, light grey triangles for adult females and dark grey diamonds for unsexed adults 


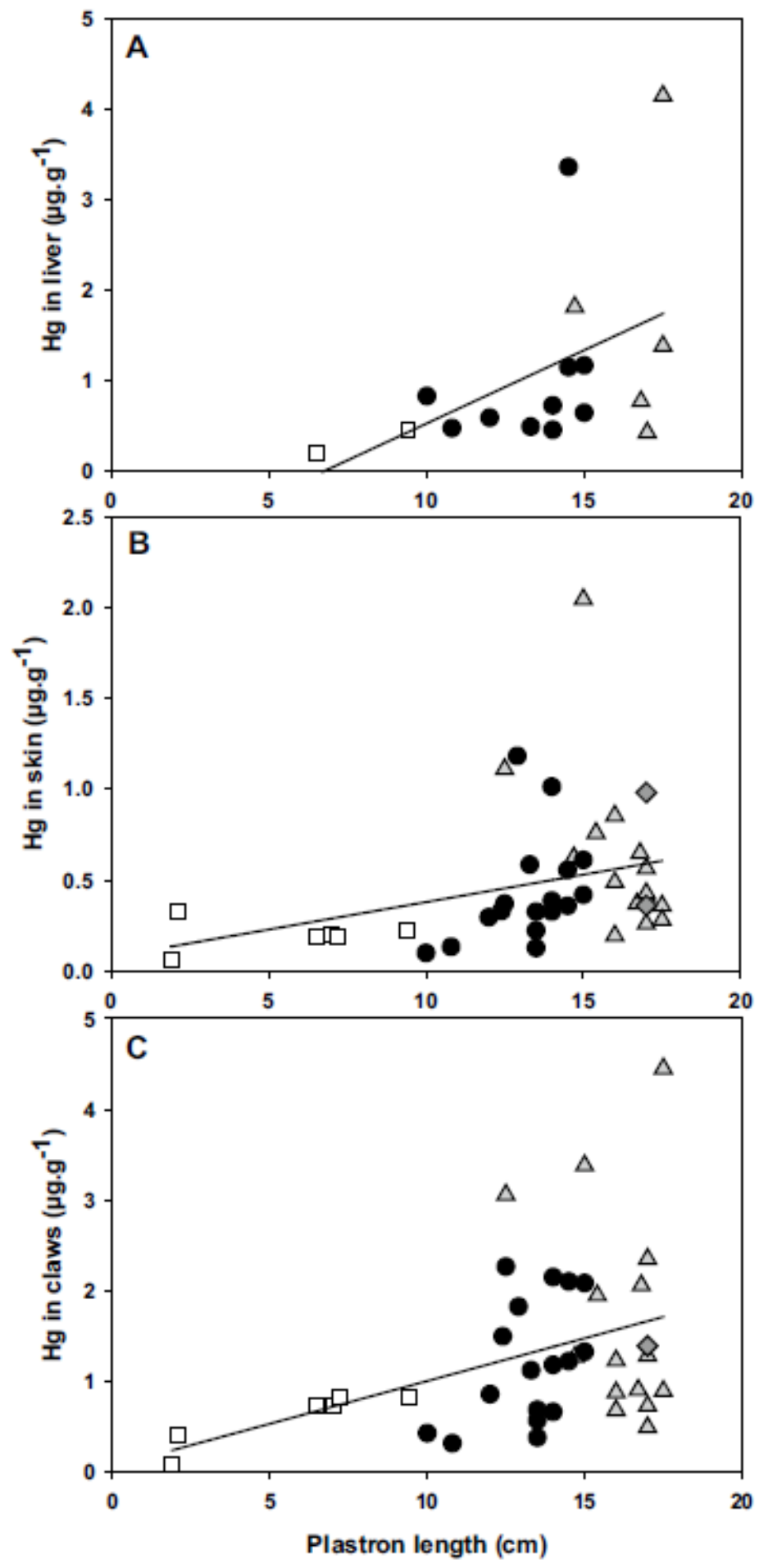

Figure 2. Relationship between turtle size (plastron length) and concentrations of $\mathrm{Hg}$ in A liver, B skin and C claws. Symbols stand as follow: white squares for juveniles, black circles for adult males, light grey triangles for adult females and dark grey diamonds for unsexed adults 